\title{
The Pelagic In situ Observation System (PELAGIOS) to reveal biodiversity, behavior, and ecology of elusive oceanic fauna
}

\author{
Henk-Jan Hoving ${ }^{1}$, Svenja Christiansen ${ }^{2}$, Eduard Fabrizius ${ }^{1}$, Helena Hauss ${ }^{1}$, Rainer Kiko ${ }^{1}$, Peter Linke ${ }^{1}$, \\ Philipp Neitzel $^{1}$, Uwe Piatkowski ${ }^{1}$, and Arne Körtzinger ${ }^{1,3}$ \\ ${ }^{1}$ GEOMAR, Helmholtz Centre for Ocean Research Kiel, Düsternbrooker Weg 20, 24105 Kiel, Germany \\ ${ }^{2}$ University of Oslo, Blindernveien 31, 0371 Oslo, Norway \\ ${ }^{3}$ Christian Albrecht University Kiel, Christian-Albrechts-Platz 4, 24118 Kiel, Germany
}

Correspondence: Henk-Jan Hoving (hhoving@geomar.de)

Received: 16 November 2018 - Discussion started: 10 December 2018

Revised: 11 June 2019 - Accepted: 17 June 2019 - Published: 7 October 2019

\begin{abstract}
There is a need for cost-efficient tools to explore deep-ocean ecosystems to collect baseline biological observations on pelagic fauna (zooplankton and nekton) and establish the vertical ecological zonation in the deep sea. The Pelagic In situ Observation System (PELAGIOS) is a $3000 \mathrm{~m}$ rated slowly $\left(0.5 \mathrm{~m} \mathrm{~s}^{-1}\right)$ towed camera system with LED illumination, an integrated oceanographic sensor set (CTD$\mathrm{O}_{2}$ ) and telemetry allowing for online data acquisition and video inspection (low definition). The high-definition video is stored on the camera and later annotated using software and related to concomitantly recorded environmental data. The PELAGIOS is particularly suitable for open-ocean observations of gelatinous fauna, which is notoriously undersampled by nets and/or destroyed by fixatives. In addition to counts, diversity, and distribution data as a function of depth and environmental conditions ( $\left.\mathrm{T}, \mathrm{S}, \mathrm{O}_{2}\right)$, in situ observations of behavior, orientation, and species interactions are collected. Here, we present an overview of the technical setup of the PELAGIOS as well as example observations and analyses from the eastern tropical North Atlantic. Comparisons to data from the Multiple Opening/Closing Net and Environmental Sensing System (MOCNESS) net sampling and data from the Underwater Vision Profiler (UVP) are provided and discussed.
\end{abstract}

\section{Introduction}

The open-ocean pelagic zones include the largest, yet least explored habitats on the planet (Robison, 2004; Webb et al., 2010; Ramirez-Llodra et al., 2010). Since the first oceanographic expeditions, oceanic communities of macrozooplankton and micronekton have been sampled using nets (Wiebe and Benfield, 2003). Such sampling has revealed a community typically consisting of crustaceans, cephalopods, fishes, and some sturdy and commonly found gelatinous fauna (Benfield et al., 1996). Underwater observations in the open ocean via scuba diving (Hamner et al., 1975) and later via submersibles (Robison, 1983; Robison and Wishner, 1990) and in situ camera systems (Picheral et al., 2010) revealed that a variety of organisms are much more abundant in the open ocean than previously estimated from net sampling (Robison, 2004). This was particularly true for fragile gelatinous zooplankton, a diverse taxonomic group, including the ctenophores and cnidarians (Remsen et al., 2004; Haddock, 2004) as well as polychaetes (Christiansen et al., 2018), Rhizaria (Biard et al., 2016), and pelagic tunicates (Remsen et al., 2004; Neitzel, 2017), which often are too delicate to be quantified using nets as they are damaged beyond identification, or they are easily destroyed by the use of common fixatives.

Underwater (in situ) observations in the pelagic ocean not only revealed a previously unknown community, they also allowed the collection of fine-scale distribution patterns of plankton in relation to biotic and abiotic factors (e.g., Haslob et al., 2009; Möller et al., 2013; Hauss et al., 2016) as well as information on posture, interactions, and behavior (Ham- 
ner and Robison, 1992; Robison, 2004; Robison, 1999; Hoving et al., 2013, 2016). Submersibles have proven to be valuable instruments to study deep-sea pelagic biology (e.g., Robison, 1987; Bush et al., 2007; Hoving et al., 2017). Using video transecting methodology, pelagic remotely operated vehicle (ROV) surveys have been applied to study interand intra-annual variation in mesopelagic zooplankton communities (Robison et al., 1998; Hull et al., 2011) and to explore deep pelagic communities in different oceans (Youngbluth et al., 2008; Hosia et al., 2017; Robison et al., 2010). However, due to high costs as well as technological and logistical challenges, regular submersible operations are still restricted to very few institutes and geographical locations. Hence, there is a need for the development of additional more cost-effective methodologies to explore and document deepsea communities via in situ observations.

In the last decades, a variety of optical instruments has been developed to image and quantify plankton in situ (Benfield et al., 2007). The factors that typically differentiate the available plankton imaging technologies are the size fraction of the observed organisms, illumination type, resolution of collected images or video, depth rating, deployment mode (e.g., autonomous, towed, CTD-mounted), and towing speed. Examples of instruments include the autonomous Underwater Vision Profiler (UVP5; Picheral et al., 2010), the Lightframe On-sight Key species Investigations (LOKI; Schulz et al., 2010) and towed plankton recorders (In Situ Ichthyoplankton Imaging System - ISIIS; Cowen and Guigand, 2008; for a review, see Benfield et al., 2007). These instruments can be deployed from ships of opportunity and collect detailed information on fine-scale distribution and diversity patterns of particles and plankton. The data reveal biological patterns on a global scale (Kiko et al., 2017) and of previously underappreciated plankton species (Biard et al., 2016). More recently, optical (and acoustic) instruments have been combined with autonomous gliders, rapidly increasing spatial resolution (Ohman et al., 2019).

Various towed camera platforms have been developed that can obtain video transect observations above the deep sea floor. Examples are the TowCam (WHOI), the DTIS (Deep Towed Imaging system, NIWA), the WASP vehicle (Wide Angle Seafloor Photography), OFOS (Ocean Floor Observation System, GEOMAR), and the more recent version OFOBS (Ocean Floor Observation and Bathymetry System; Purser et al., 2018). All these instruments are used for video or photo transects of the seafloor, with a downward looking camera and typically a set of lasers for size reference. However, published descriptions of optical systems, other than ROVs and submersibles that visualize macrozooplankton and micronekton $(>1 \mathrm{~cm})$ in the water column undisturbed by a filtering device or cuvette are, to the best of our knowledge, restricted to one (Madin et al., 2006). The Large Area Plankton Imaging System (LAPIS) is the only towed system that was developed for the documentation of larger organisms in the water column (Madin et al., 2006). LAPIS visualizes or- ganisms between 1 and $100 \mathrm{~cm}$, it combines a high-resolution color digital charge-coupled device (CCD) camera using progressive scanning interline-transfer technology with flashing strobes, and it is towed at 1 knot via a fiber optic wire. LAPIS collects still images, illumination is sideways, and organisms have to enter an illuminated volume to be visualized. Deployments in the Southern Ocean enabled the reconstruction of depth distributions of the pelagic fauna (salps, medusae) but also allowed some behavior observations, e.g., the molting of krill (Madin et al., 2006). More publications of data collected with LAPIS are unavailable to our knowledge. In addition to LAPIS, we wanted to develop a towed pelagic observation system that collects video during horizontal transects (with forward projected light), in a similar way to pelagic ROV video transects, in order to document behavior in addition to diversity, species-specific distribution, and abundance data of pelagic fauna.

The functional requirements for the instrument were (1) the ability to visualize organisms $>1 \mathrm{~cm}$ in waters down to $1000 \mathrm{~m}$ with high-definition video, (2) the possibility of deploying the instrument from ships of opportunity in an autonomous or transmitting mode, (3) for it to be lightweight and practical so it can be deployed easily and safely with two deck persons and a winch operator, (4) to enable the correlation of observations with environmental parameters $(\mathrm{S}, \mathrm{T}$, $\mathrm{O}_{2}$ ) and other sensor data, and (5) to make observations comparable to ROV video transects in other reference areas. We present a description of the Pelagic In situ Observation System (PELAGIOS), examples of the kind of biological information it may gather, as well as biological discoveries that have resulted from deployments on research cruises in the eastern tropical North Atlantic.

\section{Pelagic In Situ Observation System}

\subsection{Technical specifications}

The PELAGIOS consists of an aluminum frame (length: $2 \mathrm{~m}$ ) that carries the oceanographic equipment (Fig. 1). White light LED arrays (four LEDs produced at GEOMAR, two LED arrays of the type LightSphere of Deep-Sea Power and Light (C), which illuminate the water in front of the system, are mounted on an aluminum ring (diameter: $1.2 \mathrm{~m}$ ). Power is provided by two lithium batteries $(24 \mathrm{~V} ; 32 \mathrm{Ah})$ in a deep-sea housing. High-definition video is collected continuously by a forward-viewing deep-sea camera (1Cam Alpha, SubC Imaging ( $)$ ), which is mounted in the center of the ring. We used the maximum frame rate of 50 frames s $^{-1}$ but a lower frame rate is possible. A CTD (SBE 19 SeaCAT, Sea-Bird Scientific (C) with an oxygen sensor (SBE 43, Sea-Bird Scientific (C) records environmental data. A deepsea telemetry (DST-6, Sea and Sun Technology @; Linke et al., 2015) transmits video and CTD data to a deck unit on board allowing a low-resolution preview $(600 \times 480$ lines $)$ 


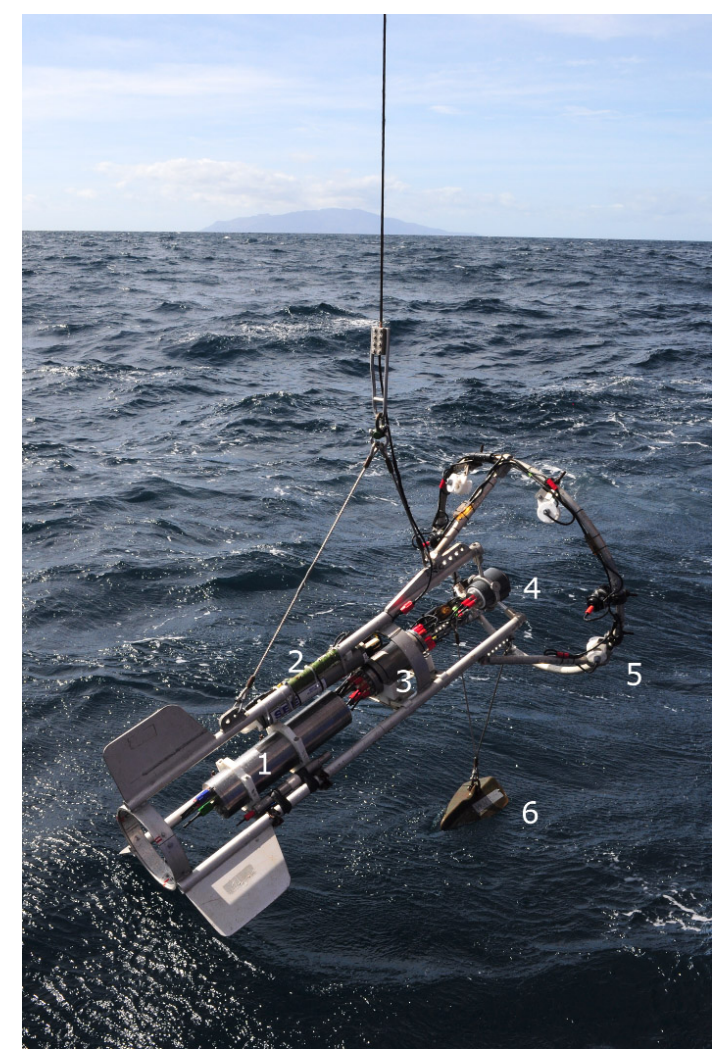

Figure 1. (a) The Pelagic In Situ Observations System (PELAGIOS) with battery (1), CTD (2), telemetry (3), camera (4), LEDs (5), and depressor (6) during deployment from R/V Poseidon in February 2018 (photo: Karen Hissmann).

of the high-definition video that is stored locally on the SD card $(256 \mathrm{~GB})$ of the camera. The power from the batteries is distributed to the LEDs via the camera. The 1Cam Alpha camera is programmable in such a way that there is a delay between providing power to the camera (by connecting to the battery) and the start of recording and switching on the LEDs. This enables the illumination to be turned on only underwater, and prevents overheating of the LED arrays while out of the water. During a cruise with the German research vessel Maria S. Merian (MSM 49) we mounted a steel scale bar in front of the camera at a distance of $1 \mathrm{~m}$. The distance between the centers of the white marks on the bar measured $5 \mathrm{~cm}$.

\subsection{Video transects}

The PELAGIOS is towed horizontally at specified depths of $20-3000 \mathrm{~m}$. The standard towing speed over ground is $1 \mathrm{knot}$ $\left(0.51 \mathrm{~m} \mathrm{~s}^{-1}\right)$, and the speed is monitored via the ship's navigational system. A video transect at a particular depth can take as long as desired and is terminated by lowering the PELAGIOS to the next depth. Maximum deployment time with full batteries is approximately $6 \mathrm{~h}$. The typical transect

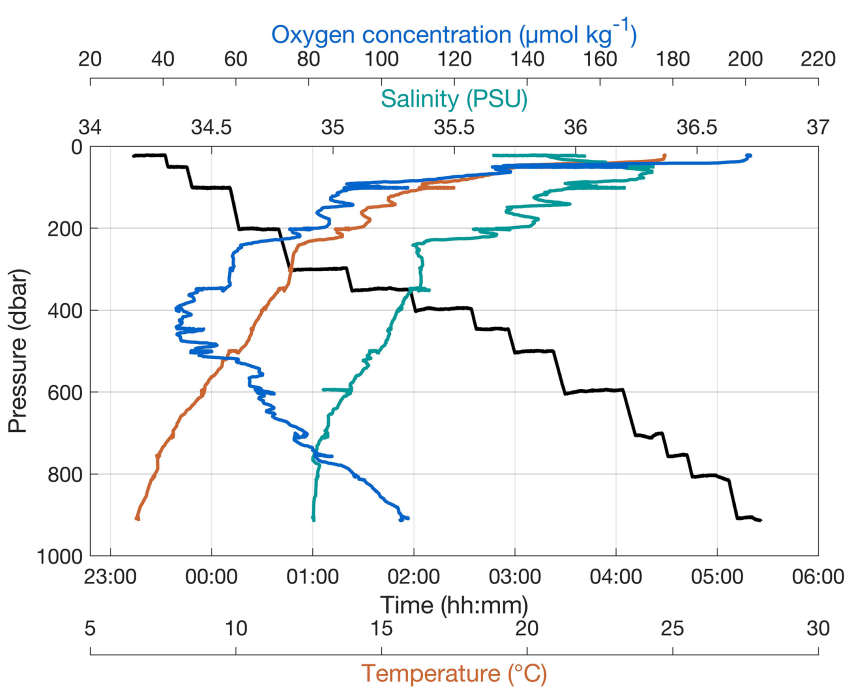

Figure 2. Stairwise trajectory of PELAGIOS through the water column, to the desired depths with concomitantly measured environmental data.

duration is $10-30 \mathrm{~min}$. The depth of the PELAGIOS can be monitored via online CTD data. Figure 2 shows the trajectories of the PELAGIOS at different depths in the water column during a video transect down to $900 \mathrm{~m}$. The deployment from deck into the water and the reverse is fast and typically takes only about $5 \mathrm{~min}$ (see video clip in the Supplement). It is possible to deploy PELAGIOS in "blind mode", where only the depth is monitored using an online depth sensor (e.g., Hydrobios (O) and the video (without transmitted preview) is recorded locally on the camera. The system can be operated completely blind (i.e., with no communication between deck and underwater unit) where the target depth is estimated from the length and angle of the wire put out, and the actual depth is recorded on the system by CTD or an offline pressure sensor, e.g., SBE Microcat $\odot$.

\subsection{Video analysis and curation}

After a deployment, the video (consisting of individual clips of $1 \mathrm{~h}$ ) is downloaded from the camera. Synchronization between video and CTD data is done by setting all instruments to UTC prior to deployment, which allows the data and video to be linked during analysis. The video is annotated using the Video Annotation and Reference System (VARS) developed at the Monterey Bay Aquarium Research Institute (Schlining and Jacobsen, 2006). This annotation program allows for frame grabs from the video, including time code. A knowledge base allows for the insertion of taxonomic names and hierarchy, and a query allows searching the created database. While many kinds of annotation software are available (for a review, see Gomes-Pereira et al., 2016), we consider VARS to be the most suitable for our purposes since it combines the features of high-resolution video playback with a user- 
friendly annotation interface and the automatic creation of an annotation database which can easily be accessed through the various search functions and tools of the query. The taxonomic hierarchy and phylogenetic trees in the database are directly applicable to our video transects. Since this software was developed by the Monterey Bay Aquarium Research Institute (MBARI), which also maintains the most extensive databases of deep pelagic observations, it makes communication about and comparison of observations and data practical. Videos are transported on hard drives after an expedition and are transferred for long-term storage on servers maintained by the central data and computing center at GEOMAR.

\subsection{Sample volume}

To estimate the sample volume of the PELAGIOS we compared video counts from the PELAGIOS with concomitantly obtained abundance data from an Underwater Vision Profiler (UVP5; Picheral et al., 2010). Four deployments from the R/V Maria S. Merian cruise MSM 49 (28 November21 December 2015, Las Palmas de Gran Canaria, Spain Mindelo, Cabo Verde) were used for the comparison where a UVP5 was mounted underneath the PELAGIOS. The UVP5 takes between 6 and 11 images per second of a defined volume $(1.03 \mathrm{~L})$ and thus enables a quantitative assessment of particle and zooplankton abundances. Objects with an equivalent spherical diameter (ESD) $>0.5 \mathrm{~mm}$ are saved as images, which can be classified into different zooplankton, phytoplankton, and particle categories. For the comparison between PELAGIOS and the UVP5, we used the pelagic polychaete Poeobius sp., as (1) this organism could be observed well on both instruments, (2) Poeobius sp. is not an active swimmer and lacks an escape response and (3) it was locally very abundant, thus providing a good basis for the direct instrument comparison.

The UVP5 images were classified as described in Christiansen et al. (2018). Poeobius sp. abundance (ind. (individuals) $\mathrm{m}^{-3}$ ) was calculated for $20 \mathrm{~s}$ time bins and all bins of one distinct depth step (with durations of 10-11 min at depths $\leq=50 \mathrm{~m}, 19-22 \mathrm{~min}$ at depths $<350 \mathrm{~m}$, and 9$11 \mathrm{~min}$ at depths $>=350 \mathrm{~m}$ ) averaged. These mean abundances were compared to the PELAGIOS counts (ind. $\mathrm{s}^{-1}$ ) of the same depth step. A linear model between the PELAGIOS counts as a function of UVP5 abundance provided a highly significant relationship (linear regression: $p<0.001$; adjusted $r^{2}=0.69$; Fig. 3). The linear regression slope $b\left(0.116 \mathrm{~m}^{3} \mathrm{~s}^{-1}\right.$; standard error $\left.0.01 \mathrm{~m}^{3} \mathrm{~s}^{-1}\right)$ between the PELAGIOS-based count $\left(C_{\text {PELAGIOS }}\right.$, ind. $\left.\mathrm{s}^{-1}\right)$ and mean UVP-based abundance $\left(A_{\mathrm{UVP}}\right.$, ind. $\left.\mathrm{m}^{-3}\right)$,

$C_{\mathrm{PELAGiOS}}=b \cdot A_{\mathrm{UVP}}+a$,

was used to estimate the volume recorded per time in cubic meters per second $(b)$ and the field of view in square meters ( $b /$ towing speed) recorded by PELAGIOS.

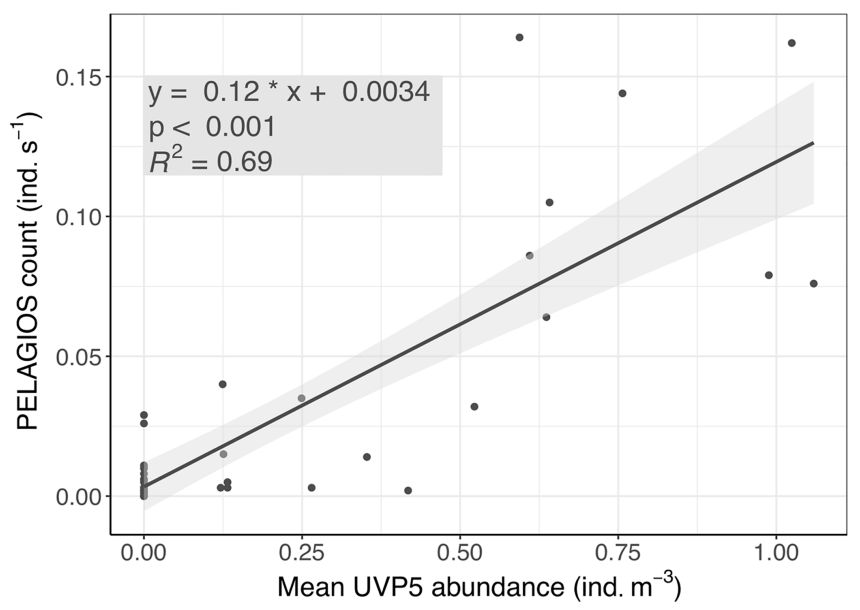

Figure 3. PELAGIOS video counts of Poeobius sp. as a function of UVP5-derived abundance on the same transects at two stations on cruise MSM 49 on R/V Maria S. Merian.

From this calculation it can be derived that PELAGIOS recorded an average volume of $0.116 \mathrm{~m}^{3} \mathrm{~s}^{-1}$ at a towing speed of 1 knot $\left(=0.51 \mathrm{~m} \mathrm{~s}^{-1}\right)$. A cross-sectional view field of approximately $0.23 \mathrm{~m}^{2}$ of PELAGIOS can be expected, compared to a theoretical field of view (FOV) of $0.45 \mathrm{~m}^{2}$ based upon the maximum image dimensions $(0.80 \mathrm{~m} \times 0.56 \mathrm{~m})$ at $1 \mathrm{~m}$ distance from the lens. We can now calculate the individuals observed by PELAGIOS per time to individuals per volume. To do so we use the number of individuals in one transect and divide this number by the duration of the transect to obtain individuals per minute, and we divide this by 60 to get the individuals per second. From the UVP-PELAGIOS comparison we derived a conversion factor of 6 to calculate the number of individuals per second to the number of individuals per cubic meter. This value is then multiplied by 1000 to go from cubic meter to $1000 \mathrm{~m}^{3}$.

\subsection{Abundance, size, and diversity}

To provide an example of the type of data that can be obtained with the PELAGIOS, we report here on day and night video transects down to $950 \mathrm{~m}$ in the eastern tropical North Atlantic, on the northwestern slope of Senghor Seamount $\left(17^{\circ} 14.2^{\prime} \mathrm{N}, 22^{\circ} 00.7^{\prime} \mathrm{W}\right.$; bottom depth of approximately $1000 \mathrm{~m}$ ). The results from the video annotations show that faunal abundances depend on the depth of deployment, and time of the day. During a transect of $21.2 \mathrm{~min}$ at $400 \mathrm{~m}, 226$ individuals $\left(1058\right.$ ind $1000 \mathrm{~m}^{-3}$ ) were encountered during the day (the three dominant groups were fishes, euphausiids, and appendicularians) compared to 196 individuals (591 ind. $1000 \mathrm{~m}^{-3}$; transect length $33.1 \mathrm{~min}$ ) during the night (the four dominant organism groups were fishes, chaetognaths, medusae, and ctenophores). Overall abundance of chaetognaths, decapods and mysids, and fishes was higher during the night. The peak of euphausiids' abun- 
dance at $400 \mathrm{~m}$ shifts to the surface at night (Fig. 4). The higher abundance of decapods and mysids and chaetognaths at night may indicate lateral migration or daytime avoidance. The vertical migration that was observed for fishes and crustaceans was much less clear for the gelatinous zooplankton groups including medusae and appendicularians (Fig. 4). Ctenophores and siphonophores were abundant in the surface at night (but we did not perform transects at $20 \mathrm{~m}$ during the day), and the thaliaceans migrated vertically and were most abundant in shallow waters at night. The total number of annotated organisms for the daytime transects (total transect time $187 \mathrm{~min}$; max depth $950 \mathrm{~m}$ ) was 835 compared to 1865 organisms for the longer nighttime transects (total transect time $292 \mathrm{~min}$; max depth 900). The high abundance of gelatinous zooplankton (128) annotated organisms ( 899 ind. $1000 \mathrm{~m}^{-3}$ ) belonging to the three dominant groups of Ctenophora (53), Siphonophorae (21), and Thaliacea (44) in the topmost layer (20 m) at night is remarkable. Below this layer, the depth profile shows a minimum in numbers of annotated individuals at 100,200, and $300 \mathrm{~m}$ water depth with a smaller peak of 57 gelatinous organisms ( 299 ind. $1000 \mathrm{~m}^{-3}$ ) at $450 \mathrm{~m}$. Compared to this, the depth distribution during the daytime shows a more regular, almost Gaussian shape with a maximum of 31 (254 ind. $1000 \mathrm{~m}^{-3}$ ) and 54 (253 ind. $1000 \mathrm{~m}^{-3}$ ) gelatinous organisms at 200 and $400 \mathrm{~m}$ water depth, respectively.

The faunal observations made by PELAGIOS include a wide variety of taxa (Table 1; Figs. 5 and 6), spanning in size from radiolarians to large siphonophores (such as Praya dubia and Apolemia). Chaetognaths were the dominant faunal group. Typical examples of fragile organisms that were not present or identifiable in the Multiple Opening/Closing Net and Environmental Sensing System (MOCNESS) samples from the same cruise (Christiansen et al., 2016; Lüskow et al., 2019) but which can be efficiently observed by PELAGIOS include large larvaceans (probably Bathochordaeus and Mesochordaeus), pelagic polychaetes (Poeobius, Tomopteris) (Fig. 5), and smaller siphonophores (such as Bargmannia and Lilyopsis; the latter can be easily distinguished by their fluorescent body parts) (Fig. 5). Observed medusae belonged to the genera Periphylla, Halitrephes, Haliscera, Crossota, Colobonema, Solmissus, and Solmundella (Fig. 5). Venus girdles (Cestum spp.), Beroe, cydippids, and ctenophores such as Thalassocalyce inconstans, Leucothea, Bathocyroe (see Harbison et al., 1978, for differences in robustness among ctenophores) were encountered (Fig. 5). Cephalopod observations were rare but small individual cranchiid squids were observed in the upper $50 \mathrm{~m}$ at night. Mastigoteuthid squids were observed with their mantle in a vertical orientation and with extended tentacles in waters below $500 \mathrm{~m}$. The large squid, Taningia danae was observed during transects. Other pelagic molluscs include the nudibranch Phylliroe and different pteropod species. Observed fishes are snipe eels, hatchet fishes, lantern fishes, and $C y$ clothone. Fishes are among the dominant organisms encoun- tered during PELAGIOS transects, but it is often impossible to identify fishes to species level from the video.

\subsection{Individual behavior}

In situ observations by PELAGIOS video may reveal direct observations on individual behavior. Decapod shrimps were observed to release a blue or green bioluminescent cloud after performing their tail flip as part of the escape response (Fig. 6d). Potential reproductive behavior was observed for two specimens of krill which were seen in what could be a mating position, and salps were observed to reproduce asexually by the release of salp oozoids (Fig. 6c). Feeding behaviors were observed for large prayid siphonophores and calycophoran siphonophores which had their tentacles extended. Poeobius worms were observed with their mucus web deployed to capture particulate matter (Christiansen et al., 2018) (Fig. 6a). Narcomedusae of the genus Solmissus were observed with their tentacles stretched up and down, which is a feeding posture. In situ observations by the PELAGIOS also showed the natural body position of pelagic organisms. Snipe eels were observed in a vertical position with their heads up, while dragonfish and some myctophids were observed in an oblique body position with their head down (Fig. 6b).

\section{Discussion}

PELAGIOS is a pelagic ocean exploration tool that fills a gap in the array of observation instruments that exist in biological oceanography, as transparent and fragile organisms $(>1 \mathrm{~cm})$ are up to now under-sampled by both net-based and optical systems. The PELAGIOS video transects are comparable to ROV video transects and can be obtained in a costeffective way. The resulting data can provide information on diversity, distribution and abundance of large $(>1 \mathrm{~cm})$, fragile zooplankton and also of some nekton and rare species. Due to the collection of HD color video, the behavior, color, and position of larger gelatinous planktonic organisms in the water column are documented, which may provide additional ecological information that cannot be obtained by nets or existing plankton recorders. The PELAGIOS system complements gear that is suitable for stratified observations and collections of robust mesozooplankton and micronekton (MOCNESS, Hydrobios Multinet, and others) and optical systems that are suitable for high-resolution sampling of small and abundant organisms (e.g., VPR, UVP5) (e.g., Benfield et al., 2007; Picheral et al., 2010; Biard et al., 2016). The instrument can be deployed with a small team and from vessels of opportunity, in transmission or blind mode. Due to the relatively simple design we experienced limited technical failures, which makes the PELAGIOS a reliable tool for oceanic expeditions. While thus far the system has only been deployed in the open ocean, it can be used in any pelagic en- 
Table 1. Taxonomic groups which were encountered during pelagic video transects with PELAGIOS in the eastern tropical Atlantic.

\begin{tabular}{|c|c|c|c|c|}
\hline Phylum & Class & Order & Family & Genus \\
\hline Cercozoa & Thecofilosea & & & \\
\hline \multicolumn{5}{|l|}{ Radiozoa } \\
\hline \multirow[t]{20}{*}{ Cnidaria } & \multirow[t]{17}{*}{ Hydrozoa } & \multirow[t]{2}{*}{ Narcomedusae } & $\begin{array}{l}\text { Solmundaeginidae } \\
\text { Aeginidae }\end{array}$ & $\begin{array}{l}\text { Solmundella } \\
\text { Aegina } \\
\text { Aeginura }\end{array}$ \\
\hline & & & Cuninidae & Solmissus \\
\hline & & \multirow[t]{3}{*}{ Trachymedusae } & Halicreatidae & $\begin{array}{l}\text { Halicreas } \\
\text { Haliscera } \\
\text { Halitrephes }\end{array}$ \\
\hline & & & Rhopalonematidae & $\begin{array}{l}\text { Colobonema } \\
\text { Crossota } \\
\text { Rhopalonema }\end{array}$ \\
\hline & & & Geryoniidae & Geryonia \\
\hline & & \multirow[t]{12}{*}{ Siphonophorae } & Agalmatidae & $\begin{array}{l}\text { Liriope } \\
\text { Halistemma } \\
\text { Marrus } \\
\text { Nanomia }\end{array}$ \\
\hline & & & Apolemiidae & Apolemia \\
\hline & & & Diphyidae & \\
\hline & & & Forskaliidae & Forskalia \\
\hline & & & Hippopodiidae & $\begin{array}{l}\text { Hippopodius } \\
\text { Vogtia }\end{array}$ \\
\hline & & & Physophoridae & Physophora \\
\hline & & & Prayidae & Craseoa \\
\hline & & & & Lilyopsis \\
\hline & & & & Praya \\
\hline & & & & Rosacea \\
\hline & & & Pyrostephidae & Bargmannia \\
\hline & & & Resomiidae & Resomia \\
\hline & Scyphozoa & Coronatae & Atollidae & Atolla \\
\hline & & & Nausithoidae & Nausithoe \\
\hline & & & Peryphyllidae & Periphylla \\
\hline \multirow[t]{9}{*}{ Ctenophora } & Nuda & Beroida & Beroidae & Beroe \\
\hline & \multirow[t]{8}{*}{ Tentaculata } & Cestida & Cestidae & $\begin{array}{l}\text { Cestum } \\
\text { Velamen }\end{array}$ \\
\hline & & \multirow{2}{*}{ Cydippida } & Aulacoctenidae & Aulacoctena \\
\hline & & & Pleurobrachiidae & Hormiphora \\
\hline & & \multirow[t]{4}{*}{ Lobata } & Bathocyroidae & Bathocyroe \\
\hline & & & Eurhamphaeidae & Kiyohimea \\
\hline & & & Leucotheidae & Leucothea \\
\hline & & & Ocryopsidae & Ocyropsis \\
\hline & & Thalassocalycida & Thalassocalycidae & Thalassocalyce \\
\hline Chaeotognatha & Sagittoidea & & & \\
\hline \multirow[t]{2}{*}{ Annelida } & \multirow[t]{2}{*}{ Polychaeta } & Phyllodocida & Tomopteridae & Tomopteris \\
\hline & & Canalipalpata & Flabelligeridae & Poeobius \\
\hline \multirow[t]{3}{*}{ Arthropoda } & Malacostraca & \multirow{3}{*}{\multicolumn{3}{|c|}{$\begin{array}{l}\text { Amphipoda } \\
\text { Decapoda } \\
\text { Euphausiacea }\end{array}$}} \\
\hline & & & & \\
\hline & & & & \\
\hline
\end{tabular}


Table 1. Continued.

\begin{tabular}{|c|c|c|c|c|}
\hline Phylum & Class & Order & Family & Genus \\
\hline & & Isopoda & Munnopsidae & Munnopsis \\
\hline \multirow[t]{6}{*}{ Mollusca } & \multirow[t]{5}{*}{ Cephalopoda } & Octopoda & $\begin{array}{l}\text { Amphitretidae } \\
\text { Octopodidae }\end{array}$ & \\
\hline & & \multirow{4}{*}{ Teuthida } & Cranchiidae & Helicocranchia \\
\hline & & & Mastigoteuthidae & Mastigoteuthis \\
\hline & & & Octopoteuthidae & $\begin{array}{l}\text { Octopoteuthis } \\
\text { Taningia }\end{array}$ \\
\hline & & & Ommastrephidae & Sthenoteuthis \\
\hline & Gastropoda & $\begin{array}{l}\text { Nudibranchia } \\
\text { Pteropoda }\end{array}$ & Phylliroidae & Phylliroe \\
\hline \multirow[t]{9}{*}{ Chordata } & Appendicularia & Copelata & Oikopleuridae & Bathochordaeus \\
\hline & & & & $\begin{array}{l}\text { Mesochor- } \\
\text { daeus }\end{array}$ \\
\hline & \multirow[t]{3}{*}{ Thaliacea } & Doliolida & & \\
\hline & & Pyrosomatida & Pyrosomatidae & Pyrostemma \\
\hline & & Salpida & Salpidae & Cyclosalpa \\
\hline & \multirow[t]{4}{*}{ Actinopteri } & Anguilliformes & Nemichthyidae & \\
\hline & & Myctophiformes & Myctophidae & \\
\hline & & Stomiiformes & Gonostomatidae & Cyclothone \\
\hline & & & Sternoptychidae & \\
\hline
\end{tabular}

vironment with water that has reasonable clearance and visibility. The data obtained after annotation of the video can be uploaded into databases (e.g., the large database PANGAEA) after publication of the results allowing for efficient data sharing and curation.

The clear distribution patterns that we observed in some animal groups (fish, crustaceans, and some gelatinous fauna) after annotating the video transects confirm that established biological processes such as diurnal vertical migration (e.g., Barham, 1963) can be detected in PELAGIOS data and that the distribution data that we observe for the organisms encountered are representative of the natural situation. It has to be noted, though, that while the observed distribution patterns should be representative, care must be taken with regard to abundance estimates of especially actively and fastswimming organisms. Some fish and crustaceans react to the presence of underwater instrumentation (e.g., Stoner et al., 2008). Gear avoidance (e.g., Kaartvedt et al., 2012) can lead to an underestimation of abundance, whereas attraction to the camera lights (e.g., Utne-Palm et al., 2018; Wiebe et al., 2003) would result in an overestimation. The large bioluminescent squid Taningia danae seemed to be attracted to the lights of the PELAGIOS, and attraction behavior of this species has been described in other publications $(\mathrm{Ku}-$ bodera et al., 2007). Compared to day transects, the high abundance of gelatinous organisms close to the surface during night is likely to be partly an effect of the higher con- trast in the videos of the night transects and better visibility of the gelatinous fauna than during day transects. Therefore, we did not perform transects shallower than $50 \mathrm{~m}$ during the day. Many of the observed gelatinous fauna might be present as well at shallow depths during daylight but are not detectable in "blue-water conditions". The difference between the taxa encountered during the day and night transect may also be due to the trapping of organisms at the slopes of Senghor Seamount during the day (Isaacs and Schwartzlose, 1965; Genin, 2004) or by other causes for patchiness (Haury et al., 2000). However, from a methodological point of view it should be noted that while the ship's towing speed is typically 1 knot, the current speeds at the survey depths may differ, also between day and night. Currents may result in a more or less sampled volume of water and hence a variation in plankton being visualized. Since abundance estimation relies on an accurate determination of the image volume, it needs to be pointed out that it is our aim to better technically constrain the image area in future developments (now derived from UVP quantitative observations) and to include flowmeter measurements.

After annotation, the PELAGIOS video transects may be used to reconstruct species-specific distribution patterns, which can be related to environmental conditions (Neitzel, 2017; Hoving et al., 2019a). Such data are also valuable for overlap comparison in distribution patterns of consumers and food items (see, e.g., Haslob et al., 2009; Möller et al., 


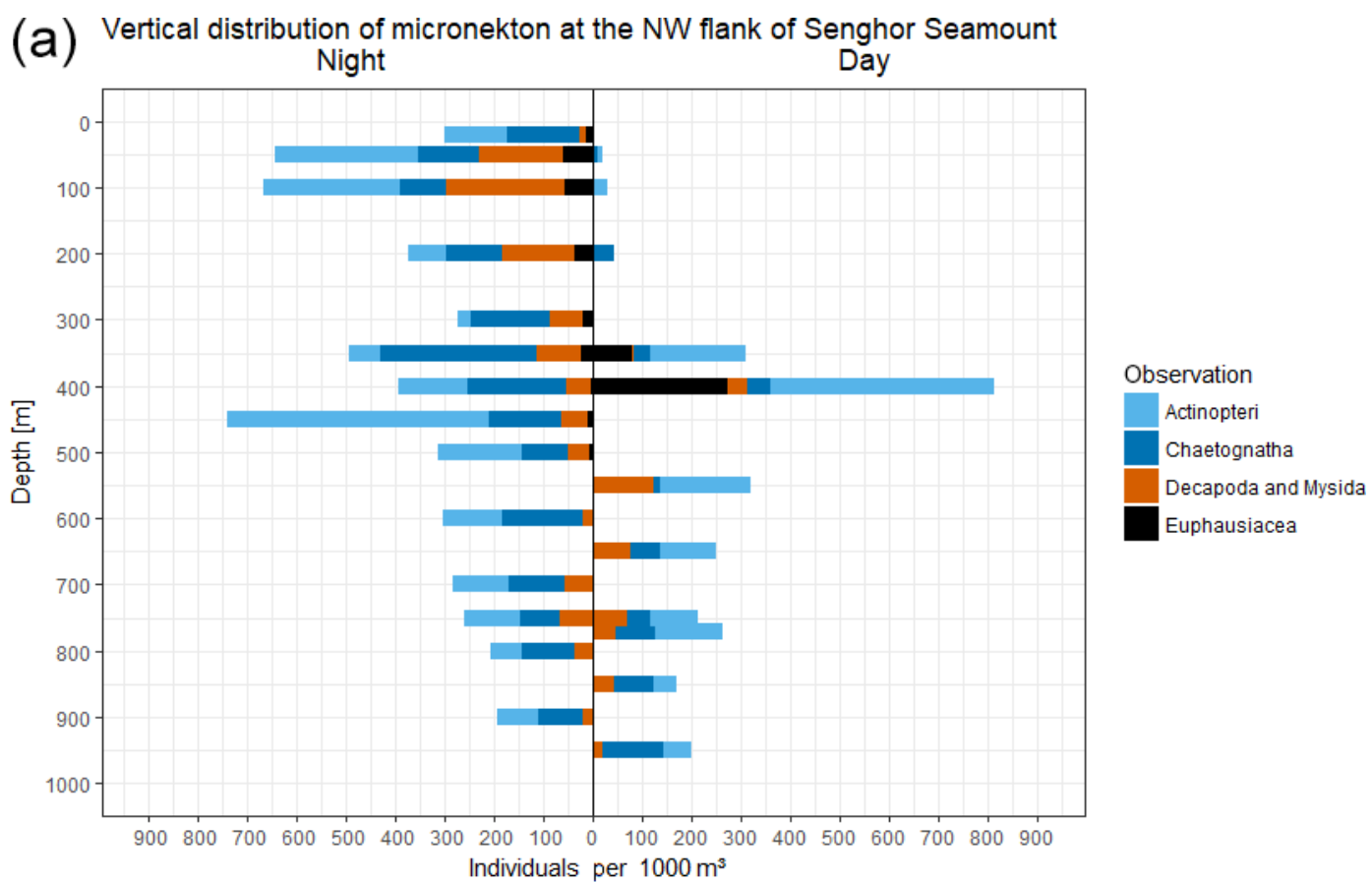

(b) Vertical distribution of gelatinous zooplankton at the NW flank of Senghor Seamount
Night

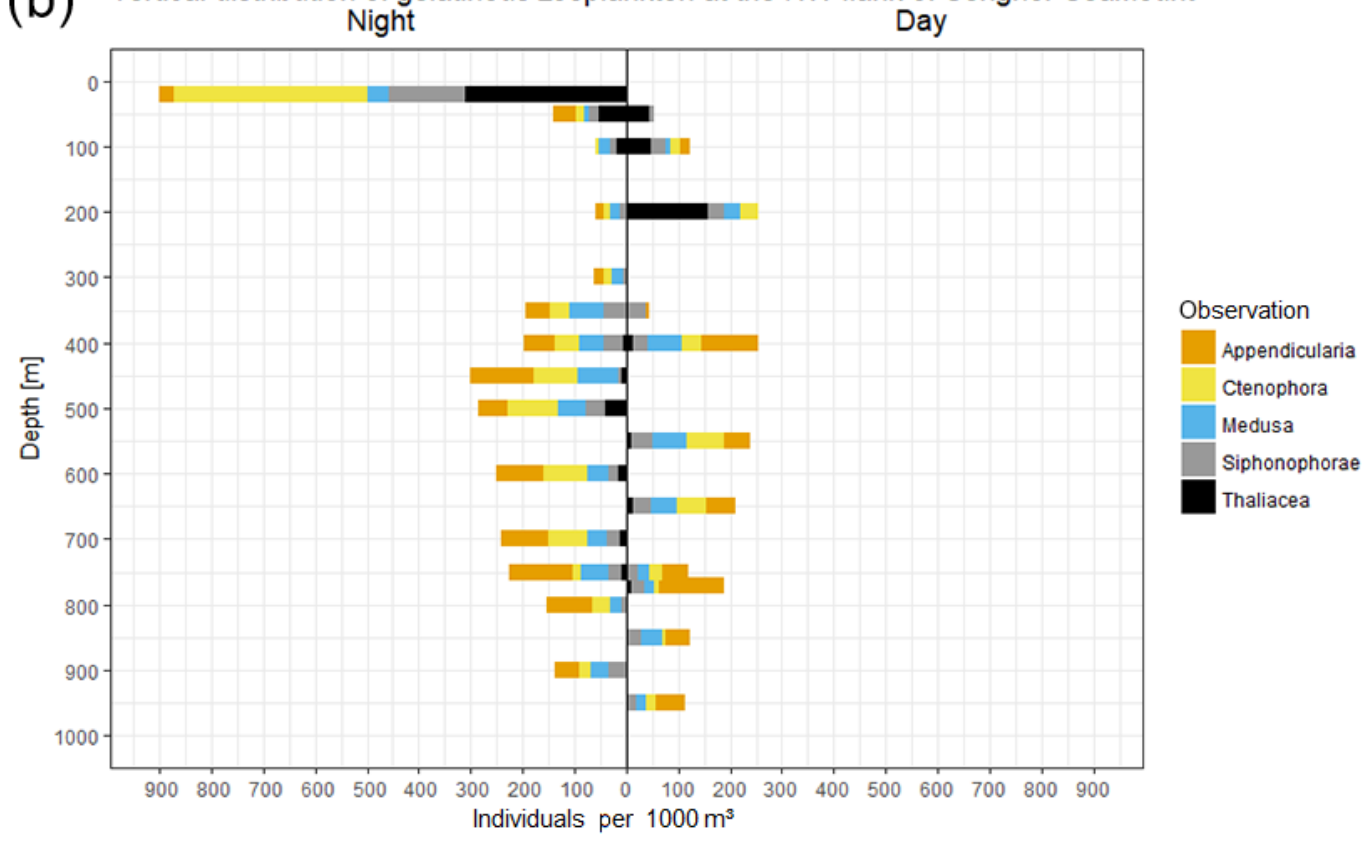

Figure 4. Day and night comparison of faunal observations obtained by PELAGIOS at the northwest flank of Senghor Seamount: (a) fishes, krill, chaetognaths, and decapods; (b) gelatinous zooplankton groups.

2012). The data can also be used in biological studies that aim to predict the consequences of a changing ocean with altering oceanographic features and conditions for species' distributions, as has been done for net sampling of mesozooplankton (Wishner et al., 2013). One example of changing oceanographic conditions is the global trend of oxygen loss in the world oceans (Oschlies et al., 2018). Oxygen mini- mum zones (OMZs) occur naturally in the mesopelagic zone (Robinson et al., 2010), and in different oceans they have been found to expand horizontally and vertically as a result of climate change (Stramma et al., 2008; Oschlies et al., 2018). The expansion of OMZs may result in a habitat reduction of the pelagic fauna (e.g., Stramma et al., 2012) or increase the habitat for species with hypoxia tolerance (Gilly et al., 


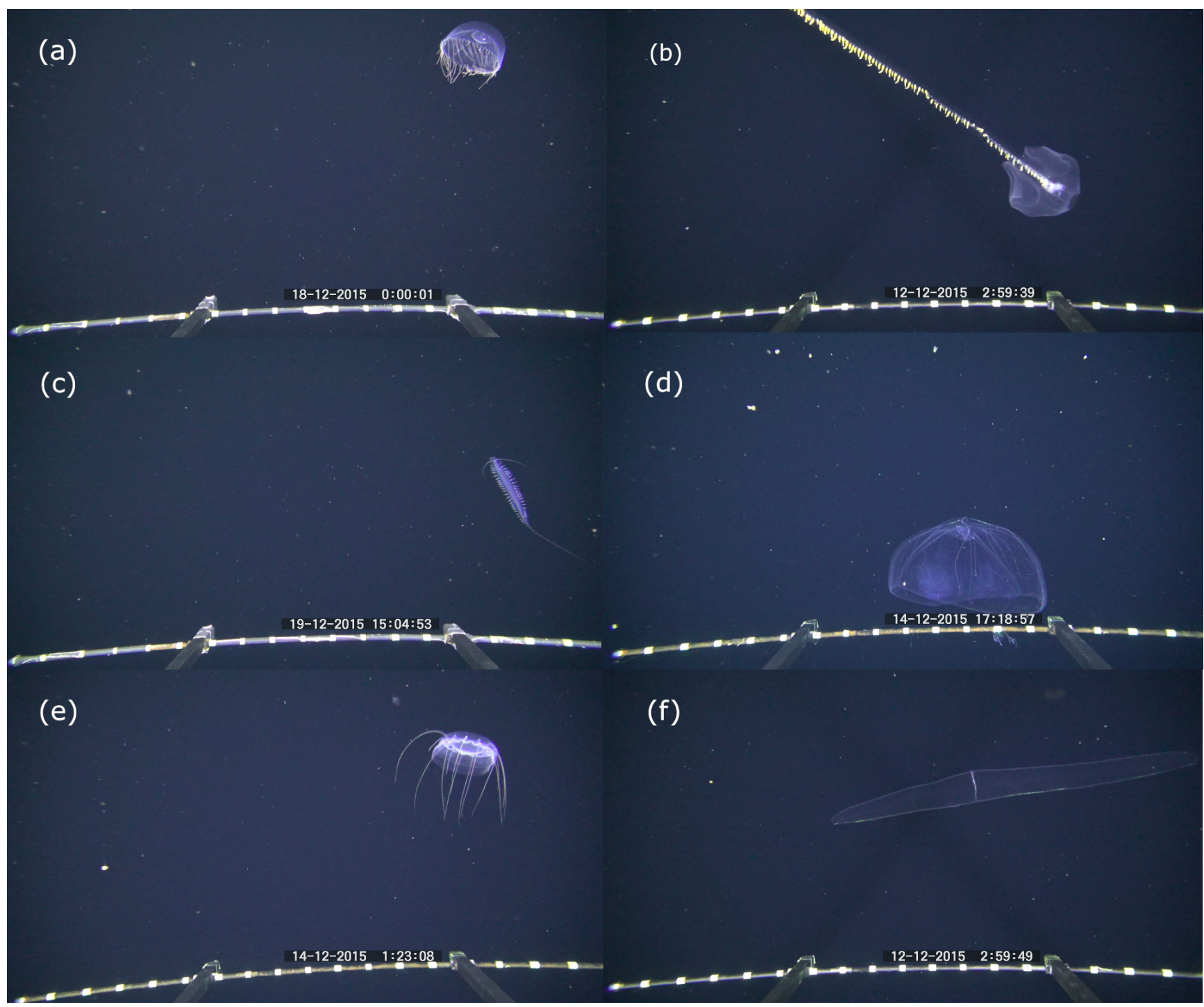

Figure 5. Examples of organisms encountered during pelagic video transects with PELAGIOS during cruise MSM49 in the eastern tropical Atlantic. (a) A medusa Halitrephes sp. (b) A siphonophore Praya dubia. (c) A tomopterid worm. (d) The ctenophore Thalassocalyce inconstans. (e) The medusa Solmissus. (f) The ctenophore Cestum. The distance between the white bands on the horizontal bar on the bottom of the images is $5 \mathrm{~cm}$.

2013). To predict the potential consequences of OMZ expansion for pelagic invertebrates, we investigated the abundance and distribution of distinct large gelatinous zooplankton species, including medusae, ctenophores, siphonophores, and appendicularians, in the eastern tropical North Atlantic using PELAGIOS video transects and correlated the biological patterns to the oxygen gradients (Neitzel, 2017; Hoving et al., 2019a).

During various cruises, the UVP5 was mounted underneath the PELAGIOS providing concomitant data on macrozooplankton and nekton (PELAGIOS) as well as particles and mesozooplankton (UVP5). The combination of the two instruments provides a great opportunity to assess both the mesopelagic fauna and particles during one sampling event. The joint deployment of the PELAGIOS and UVP5 also allowed an estimation of the sampled water volume of the PELAGIOS as described above. The linear relationship between counts of the nonmoving Poeobius sp. with UVP5 and the PELAGIOS indicates the comparability of the two different methods for animals in this size class and provides a correction factor to estimate organism abundance (ind. $\mathrm{m}^{-3}$ ) from PELAGIOS count (ind. $\mathrm{s}^{-1}$ ) data.

The field of view (FOV) derived from the UVP5 comparison for the PELAGIOS was estimated to be $0.23 \mathrm{~m}^{2}$ in comparison to $0.45 \mathrm{~m}^{2}$ based on measurement of the scale bar at $1 \mathrm{~m}$ from the camera. The angle of view of the PELAGIOS 


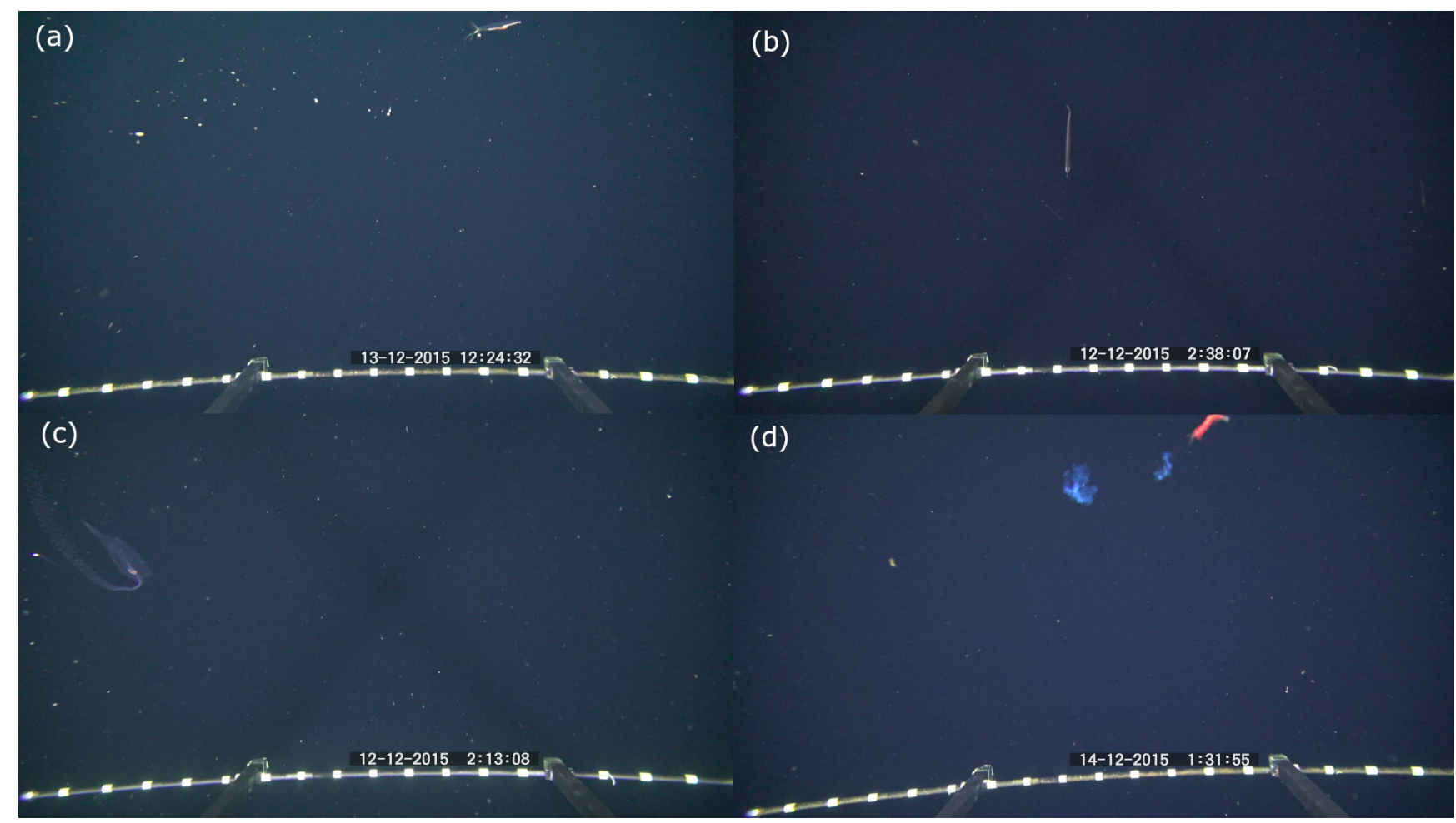

Figure 6. Examples of behaviors observed during pelagic video transects with the PELAGIOS. (a) Poeobius sp. in a feeding position with a mucus web (left side of the animal); (b) a dragonfish of the family Stomiidae in a vertical position; (c) a salp releasing a blastozoid chain; (d) a crustacean releasing two bioluminescent clouds while performing an escape response. The distance between the white bands on the horizontal bar on the bottom of the images is $5 \mathrm{~cm}$.

is $80^{\circ}$, and therefore the field of view (FOV) is much smaller than the FOV of video transects with a wide-angle lens, e.g., by ROV Tiburon (Robison et al., 2010). When comparing the FOV, it is important to take into account the object that is observed. We provided an estimate of the FOV using Poeobius sp., which is a small organism that can be detected only when it is close to the camera. Therefore, the area of the FOV for the quantification of Poeobius sp. is smaller than when quantifying larger organisms, and the initial identification distance differs between species (Reisenbichler et al., 2016).

We compared PELAGIOS video transects with MOCNESS net (opening $1 \mathrm{~m}^{2}$ ) abundance data by integrating the PELAGIOS counts over the respective depth strata of the MOCNESS that happened at the same cruise (Lüskow et al., 2019). The diversity of the gelatinous zooplankton in the total MOCNESS catch is much lower (eight different taxa) (Lüskow et al., 2019) than in the pooled video transects (53 different annotated taxa) at the same station. The ctenophore Beroe is an example of a gelatinous organism captured in MOCNESS hauls and also observed on PELAGIOS transects. Normalization and subsequent standardization of the encountered Beroe in MOCNESS and PELAGIOS transects show that on the same station and the same depths, PELAGIOS observes 3-5 times more Beroe at the three depths where they were encountered by both instruments. Additionally, the PELAGIOS also repeatedly observed Beroe at depths where they were not captured by MOCNESS at all (although there were also depths where PELAGIOS did not observe any Beroe). Preliminary comparisons of the data obtained with PELAGIOS and with MOCNESS indicate substantial differences in the documented fauna, a phenomenon also observed in previous comparisons between optical and net data (Remsen et al., 2004). Many more gelatinous taxa were observed during PELAGIOS video transects than were captured in MOCNESS catches at the same station (data presented here, Lüskow et al., 2019) due to the delicate nature of many ctenophores, medusae, and siphonophores, preventing their intact capture by nets. A notable exception are the small and robust calycophoran colonies of the families Diphyidae and Abylidae, which were also captured by MOCNESS. In contrast, avoidance behavior of strongly and fast-swimming jellyfish (e.g., Atolla, Periphylla), which may escape from the relatively slowly towed PELAGIOS, may explain their increased occurrence in nets compared to video recordings. While PELAGIOS is certainly suitable for visualizing delicate gelatinous fauna, it cannot replace net or ROV sampling since complementary specimen collections are needed to validate the identity of organisms that were observed during PELAGIOS video observations. Therefore, it is desired 
that net tows with open and closing nets such as Multinet Maxi or MOCNESS are performed in the same areas or that collections during submersible dives are made. An advantage of ROVs over PELAGIOS is the ROV's ability to stop on organisms for detailed close-up recording and potentially the collection of the observed organisms. This is not possible with PELAGIOS as the ship tows the instrument.

While the imaging processing pipeline is not as streamlined as in other optical systems that use still images such as the VPR or the UVP5, the potential of the PELAGIOS as an exploration tool is illustrated by the discovery of previously undocumented animals. An example is the ctenophore Kiyohimea usagi (Matsumoto and Robison, 1992), which was observed seven times by the PELAGIOS and once by the manned submersible JAGO during cruises in the eastern tropical North Atlantic. This large ( $>40 \mathrm{~cm}$ wide) lobate ctenophore was previously unknown from the Atlantic Ocean and demonstrates how in situ observations in epipelagic waters can result in the discovery of relatively large fauna (Hoving et al., 2018). Since gelatinous organisms are increasingly recognized as vital players in the oceanic food web (Choy et al., 2017) and in the biological carbon pump (Robison et al., 2005), in situ observations with tools like the PELAGIOS can provide new important insights into the oceanic ecosystem and the carbon cycle. But small gelatinous organisms may also have a large biogeochemical impact on their environment. This was illustrated by the discovery of the pelagic polychaete Poeobius sp. during the PELAGIOS video transects in the eastern tropical North Atlantic (Christiansen et al., 2018). The observations of the PELAGIOS provided the first evidence for the occurrence of Poeobius sp. in the Atlantic Ocean. During the R/V Meteor cruise M119, Poeobius was found to be extremely abundant in a mesoscale eddy. Following this discovery, it was possible to reconstruct the horizontal and vertical distribution of Atlantic Poeobius in great detail using an extensive database of the UVP5 (956 vertical CTD or UVP5 profiles) in the eastern tropical North Atlantic, and to establish that the high local abundance of Poeobius was directly related to the presence of mesoscale eddies in which they substantially intercepted the particle export flux to the deep sea (Christiansen et al., 2018).

Future effort should be focused on improving the assessment of the sample volume by integrating technology that can quantify it (e.g., current meters, a stereo-camera setup or a laser-based system). A stereo-camera set up would also allow for size measurements of the observed organisms, which could be beneficial to estimate the biomass of the observed organisms from published size-to-weight relationships. It might also be possible to obtain similar information based on structure-from-motion approaches that proved successful in benthic video imaging (Burns et al., 2015). The PELAGIOS system can also be a platform for other sensors. For example, the PELAGIOS was used to mount and test the TuLUMIS multispectral camera (Liu et al., 2018). Future developments include the preparation of the system for deploy- ments down to $6000 \mathrm{~m}$ water depth. The integration of acoustic sensors would be valuable to measure the target strength of camera-observed organisms, to estimate gear avoidance or attraction, and to estimate biomass and the abundance of organisms outside the field of view of the camera. We strongly encourage the use of complementary instruments to tackle the relative importance of a wide range of organisms in the oceanic pelagic ecosystem.

Data availability. The datasets generated and/or analyzed during the current study are available in the PANGAEA repository: https://doi.org/10.1594/PANGAEA.902247 (Hoving et al., 2019b).

Author contributions. This instrument was designed, tested and applied by HJH and EF. RK and HH developed the idea of combining the PELAGIOS with the UVP5. PN and SC analyzed the data in this paper in consultation with HJH, RK, and HH. AK, UP, and PL added valuable input to the further development of the instrument and its application and/or the data interpretation. All authors contributed to writing the paper. All authors approved the final submitted paper.

Competing interests. The authors declare that they have no conflict of interest.

Acknowledgements. Our sincere gratitude goes to Ralf Schwarz, Sven Sturm, and other colleagues of GEOMAR's Technology and Logistics Centre as well as Svend Mees for their indispensable support in design and construction during the development of PELAGIOS. We want to thank the crew of the research vessels Meteor, Maria S. Merian, and Poseidon for their excellent support during research expeditions and Bernd Christiansen (University of Hamburg) for collaboration and leading the expedition MSM49. Anneke Denda and Florian Lüskow are acknowledged for their help on the MOCNESS samples of gelatinous zooplankton collected during MSM49. Shiptime on R/V Maria S. Merian and supporting funds were provided by the German Research Foundation (DFG) (grant MSM49 to Bernd Christiansen). We also thank the DFG for providing financial support to HJH under grants HO 5569/1-2 (Emmy Noether Junior Research Group) and grant CP1218 of the Cluster of Excellence 80 "The Future Ocean". Rainer Kiko and Svenja Christiansen were supported by grant CP1650 of the Cluster of Excellence 80 "The Future Ocean". "The Future Ocean" is funded within the framework of the Excellence Initiative by the DFG on behalf of the German federal and state governments. Rainer Kiko and Helena Hauss were supported by the DFG as part of the Collaborative Research Centre (SFB) 754 "Climate-Biogeochemistry Interactions in the Tropical Ocean".

Financial support. This research has been supported by the German Research Foundation (grant nos. HO 5569/1-2, CP1218, CP1650, and SFB754). 
Review statement. This paper was edited by Mario Hoppema and reviewed by two anonymous referees.

\section{References}

Barham, E. G.: Siphonophores and the deep scattering layer, Science, 140, 826-828, 1963.

Benfield, M. C., Davis, C. S., Wiebe, P. H., Gallager, S. M., Lough, R. G., and Copley, N. J.: Video Plankton Recorder estimates of copepod, pteropod and larvacean distributions from a stratified region of Georges Bank with comparative measurements from a MOCNESS sampler, Deep-Sea Res. Pt. II, 43, 1925-1945, 1996.

Benfield, M. C., Grosjean, P., Culverhouse, P. F., Irigoien, X., Sieracki, M. E., Lopez-Urrutia, A., Dam, H. G., Hu, Q., Davis, C. S., Hansen, A., Pilskaln, C. H., Riseman, E. M., Schultz, H., Utgoff,, P. E., and Gorsky, G.: RAPID: Research on Automated Plankton Identification, Oceanography, 20, 172-187, 2007.

Biard, T., Picheral, M., Mayot, N., Vandromme, P., Hauss, H., Gorsky, G., Guid, L., Kiko, R., and Not, F.: In situ imaging reveals the biomass of giant protists in the global ocean, Nature, 532, 504-507, 2016.

Burns, J. H. R., Delparte, D., Gates, R. D., and Takabayashi, M.: Integrating structure-from-motion photogrammetry with geospatial software as a novel technique for quantifying 3D ecological characteristics of coral reefs, PeerJ, 3, e1077, https://doi.org/10.7717/peerj.1077, 2015.

Bush, S. L., Caldwell, R. L., and Robison, B. H.: Ink utilization by mesopelagic squid, Mar. Biol., 152, 485-494, 2007.

Choy, C. A., Haddock, S. H. D., and Robison, B. H.: Deep pelagic food web structure as revealed by in situ feeding observations, Proc. R. Soc. B. Biol. Sci., 284, 1869, https://doi.org/10.1098/rspb.2017.2116, 2017.

Christiansen, B., Buchholz, C., Buchholz, F., Chi, X., Christiansen, S., Denda, A., Fabrizius, E., Hauss, H., Hoving, H. J. T., Janßen, S., Kaufmann, M., Kronschnabel, A., Lischka, A., Lüskow, F., Martin, B., Merten, V., Silva, P., Pinheiro, N., Springer, B., Zankl, S., and Zeimet, T.: SEAMOX: The Influence of Seamounts and Oxygen Minimum Zones on Pelagic Fauna in the Eastern Tropical Atlantic, Technical Cruise Report Cruise No. MSM49 28 November-21 December 2015 Las Palmas de Gran Canaria (Spain)-Mindelo (Republic of Cape Verde), 2016.

Christiansen, S., Hoving, H. J. T., Schütte, F., Hauss, H., Karstensen, J. Körtzinger, A., Schröder, M., Stemmann, L., Christiansen, B., Picheral, M., Brandt, P., Robison, B. H., Koch, R., and Kiko, R.: Particulate matter flux interception in oceanic mesoscale eddies by the polychaete Poeobius sp., Limnol. Oceanogr., 63, 2093-2109, 2018.

Cowen, R. K. and Guigand, C. M.: In situ ichthyoplankton imaging system (ISIIS): system design and preliminary results, Limnol. Oceanogr.-Meth, 6, 126-132, 2008.

Genin, A.: Bio-physical coupling in the formation of zooplankton and fish aggregations over abrupt topographies, J. Marine Syst., 50, 3-20, 2004.

Gilly, W. F., Beman, J. M., Litvin, S. Y., and Robison, B. H.: Oceanographic and biological effects of shoaling of the oxygen minimum zone, Annual Review in Marine Science, 5, 393-420, 2013.
Gomes-Pereira, J. N., Auger, V., Beisiegel, K., Benjamin, R., Bergmann, M., Bowden, D., Buhl-Mortensen, P., De Leo, F. C., Dionísio, G., Durden, J. M., Edwards, L., Friedman, A., Greinert, J., Jacobsen-Stout, N., Lerner, S., Leslie, M., Nattkemper, T. W., Sameoto, J. A., Schoening, T., Schouten, R., Seager, J., Singh, H., Soubigou, O., Tojeira, I., van den Beld, I., Dias, F., Tempera, F., and Santos, R. S.: Current and future trends in marine image annotation software, Prog. Oceanogr., 149, 106-120, 2016.

Haddock, S. H. D.: A golden age of gelata: past and future research on planktonic ctenophores and cnidarians, Hydrobiologia, 530, 549-556, 2004.

Hamner, W. M., Madin, L. P., Alldredge, A. L., Gilmer, R. M., and Hamner, P. P.: Underwater observations of gelatinous zooplankton: sampling problems, feeding biology and behavior, Limnol. Oceanogr., 20, 907-917, 1975.

Hamner, W. M. and Robison, B. H.: In situ observations of giant appendicularians in Monterey Bay, Deep-Sea Res., 39, 1299-1313, 1992.

Harbison, G., Madin, L., and Swanberg, N.: On the natural history and distribution of oceanic ctenophores, Deep-Sea Res., 25, 233 256, 1978.

Haslob, H., Rohlf, N., and Schnack, D.: Small scale distribution patterns and vertical migration of North Sea herring larvae (Clupea harengus, Teleostei: Clupeidae) in relation to abiotic and biotic factors, Sci. Mar., 73, 13-22, 2009.

Haury, L., Fey, C., Newland, C., and Genin, A.: Zooplankton distribution around four eastern North Pacific seamounts, Prog. Oceanogr., 45, 69-105, 2000.

Hauss, H., Christiansen, S., Schütte, F., Kiko, R., Edvam Lima, M., Rodrigues, E., Karstensen, J., Löscher, C. R., Körtzinger, A., and Fiedler, B.: Dead zone or oasis in the open ocean? Zooplankton distribution and migration in low-oxygen modewater eddies, Biogeosciences, 13, 1977-1989, https://doi.org/10.5194/bg-131977-2016, 2016.

Hosia, A., Falkenhaug, T., Baxter, E. J., and Pagès, F.: Abundance, distribution and diversity of gelatinous predators along the Mid Atlantic Ridge: A comparison of different sampling methodologies, PLoS One, 12, e0187491, https://doi.org/10.1371/journal.pone.0187491, 2017.

Hoving, H. J. T. and Robison, B. H.: Deep-sea in situ observations of gonatid squid and their prey reveal high occurrence of cannibalism, Deep-Sea Res. Pt. I, 116, 94-98, 2016.

Hoving, H. J. T., Zeidberg, L., Benfield, M., Bush, S., Robison, B. H., and Vecchione, M.: First in situ observations of the deep-sea squid Grimalditeuthis bonplandi reveals unique use of tentacles, Proc. R. Soc. B, 280, 1769, https://doi.org/10.1098/rspb.2013.1463, 2013.

Hoving, H. J. T., Bush, S. L., Haddock, S. H. D., and Robison, B. H.: Bathyal feasting: post-spawning squid as a source of carbon for deep-sea benthic communities, Proc. R. Soc. B, 284, 20172096, https://doi.org/10.1098/rspb.2017.2096, 2017.

Hoving, H.-J., Neitzel, P., and Robison, B.: In situ observations lead to the discovery of the large ctenophore Kiyohimea usagi (Lobata: Eurhamphaeidae) in the eastern tropical Atlantic, Zootaxa, 4526, 232-238, 2018.

Hoving, H. J. T. et al.: Vertical ecology of gelatinous fauna in relation to the mesopelagic oxygen minimum zone of the eastern Atlantic, in preparation, 2019a. 
Hoving, H.-J. T., Christiansen, S., Fabrizius, E., Hauss, H., Kiko, R., Linke, P., Neitzel, P., Piatkowski, U., and Körtzinger, A.: Data from video supporting the technological description of the pelagic in situ observation system PELAGIOS, PANGAEA, https://doi.org/10.1594/PANGAEA.902247, 2019 b.

Hull, P. M., Osborn, K. J., Norris, R. D., and Robison, B. H.: Seasonality and depth distribution of a mesopelagic foraminifer, Hastigerinella digitata, in Monterey Bay, California, Limnol. Oceanogr., 56, 562-576, 2011.

Isaacs, J. D. and Schwartzlose, R. A.: Migrant sound scatterers: interaction with the sea floor, Science, 150, 1810-1813, 1965.

Kaartvedt, S., Staby, A., and Aksens, D. L.: Efficient trawl avoidance by mesopelagic fishes causes large underestimation of their biomass, Mar. Ecol. Prog. Ser., 456, 1-6, 2012.

Kiko, R., Biastoch, A., Brandt, P., Cravatte, S., Hauss, H., Hummels, R., Kriest, I., Marin, F., McDonnell, A. M. P., Oschlies, A., Picheral, M., Schwarzkopf, F. U., Thurnherr, A. M., and Stemmann, L.: Biological and physical influences on marine snowfall at the equator, Nat. Geosci., 42, 852-858, 2017.

Kubodera, T., Koyama, Y., and Mori, K.: Observations of wild hunting behaviour and bioluminescence of a large deep-sea, eightarmed squid, Taningia danae, P. Roy. Soc. B, 274, 1029-1034, 2007.

Linke, P., Schmidt, M., Rohleder, M., Al-Barakati, A., and AlFarawati, R.: Novel online digital video and high-speed data broadcasting via standard coaxial cable onboard marine operating vessels, Mar. Tech. Soc. J., 49, 7-18, 2015.

Liu, H., Sticklus, J., Köser, K., Hoving, H. J. T., Ying, C., Hong, S., Greinert, J., and Schoening, T.: TuLUMIS - A tunable LEDbased underwater multispectral imaging system, Opt. Express, 26, 7811-7828, 2018.

Lüskow, F., Hoving, H. J. T., Christiansen, B., Chi, X., Silva, P., Neitzel, P., and Jaspers, C.: Distribution and biomass of gelatinous zooplankton in relation to an oxygen minimum zone and a shallow seamount in the Eastern Tropical Atlantic Ocean, in preparation, 2019.

Madin, L., Horgan, E., Gallager, S., Eaton, J., and Girard, A.: LAPIS: A new imaging tool for macrozooplankton, IEEE J. Oceanic Eng., https://doi.org/10.1109/OCEANS.2006.307106, 1-4244-0115-1/06, 2006.

Matsumoto, G. I. and Robison, B. H.: Kiyohimea usagi, a new species of lobate ctenophore from the Monterey Submarine Canyon, B. Mar. Sci., 51, 19-29, 1992.

Möller, K. O., John, M. S., Temming, A., Floeter, J., Sell, A. F., Herrmann, J.-P., and Möllmann, C.: Marine snow, zooplankton and thin layers: indications of a trophic link from small-scale sampling with the Video Plankton Recorder, Mar. Ecol. Prog. Ser., 468, 57-69, 2012.

Neitzel, P.: The impact of the oxygen minimum zone on the vertical distribution and abundance of gelatinous macrozooplankton in the Eastern Tropical Atlantic. MSc Thesis, Christian-AlbrechtsUniversität Kiel, Germany, 75 pp., 2017.

Ohman, M. D., Davis, R. E., Sherman, J. T., Grindley, K. R., Whitmore, B. M., Nickels, C. F., and Ellen, J. S.: Zooglider: An autonomous vehicle for optical and acoustic sensing of zooplankton, Limnol. Oceanogr.-Meth., 17, 69-86, 2019.

Oschlies, A., Brandt, P., Stramma, L., and Schmidtko, S.: Drivers and mechanisms of ocean deoxygenation, Nat. Geosci., 11, 467473, 2018.
Picheral, M., Guidi, L., Stemmann, L., Karl, D. M., Iddaoud, G., and Gorsky, G.: The Underwater Vision Profiler 5: An advanced instrument for high spatial resolution studies of particle size spectra and zooplankton, Limnol. Oceangr.-Meth., 8, 462-473, 2010.

Purser, A., Marcon, Y., Dreutter, S., Hoge, U., Sablotny, B., Hehemann, L., Lemburg, J., Dorschel, B., Biebow, H., and Boetius, A.: Ocean floor observation and bathymetry system (OFOBS): A new towed camera/sonar system for deep-sea habitat surveys, IEEE J. Oceanic Eng., 44, 87-99, 2018.

Ramirez-Llodra, E., Brandt, A., Danovaro, R., De Mol, B., Escobar, E., German, C. R., Levin, L. A., Martinez Arbizu, P., Menot, L., Buhl-Mortensen, P., Narayanaswamy, B. E., Smith, C. R., Tittensor, D. P., Tyler, P. A., Vanreusel, A., and Vecchione, M.: Deep, diverse and definitely different: unique attributes of the world's largest ecosystem, Biogeosciences, 7, 2851-2899, https://doi.org/10.5194/bg-7-2851-2010, 2010.

Reisenbichler, K. R., Chaffey, M. R., Cazenave, F., McEwen, R. S., Henthorn, R. G., Sherlock, R. E., and Robison, B. H.: Automating MBARI's midwater time-series video surveys: the transition from ROV to AUV, IEEE J. Ocean Eng., OCEANS 2016 MTS/IEEE Monterey, https://doi.org/10.1109/OCEANS.2016.7761499, 2016.

Remsen, A., Hopkins, T. L., and Samson, S.: What you see is not what you catch: a comparison of concurrently collected net, Optical Plankton Counter, and Shadowed Image Particle Profiling Evaluation Recorder data from the northeast Gulf of Mexico, Deep-Sea Res. Pt. I, 51, 129-151, 2004.

Robinson, C., Steinberg, D. K., Anderson, T. R., Arístegui, J., Carlson, C. A., Frost, J. R., Ghiglione, J.-F., Hernández-León, S., Jackson, G. A., Koppelmann, R., Quéguiner, B., Ragueneau, O., Rassoulzadegan, F., Robison, B. H., Tamburini, C., Tanaka, T., Wishner, K. F., and Zhang, J.: Mesopelagic zone ecology and biogeochemistry - a synthesis, Deep-Sea Res. Pt. II, 57, 15041518, 2010.

Robison, B. H.: Midwater biological research with the WASP ADS, Mar. Tech. Soc. J., 17, 21-27, 1983.

Robison, B. H.: The coevolution of undersea vehicles and deep-sea research, Mar. Tech. Soc. J., 33, 65-73, 1999.

Robison, B. H.: Deep pelagic biology, J. Exp. Mar. Boil. Ecol., 300, 253-272, 2004.

Robison, B. H. and Wishner, K.: Biological research needs for submersible access to the greatest ocean depths, Mar. Tech. Soc. J., 24, 34-37, 1990.

Robison, B. H., Reisenbichler, K. R., Sherlock, R. E., Silguero, J. M. B., and Chavez, F. P.: Seasonal abundance of the siphonophore, Nanomia bijuga, in Monterey Bay, Deep-Sea Res. II, 45, 1741-1752, 1998.

Robison, B. H., Reisenbichler, K. R., and Sherlock, R. E.: Giant larvacean houses: rapid carbon transport to the deep sea floor, Science, 308, 1609-1611, 2005.

Robison, B. H., Sherlock, R. E., and Reisenbichler, K.: The bathypelagic community of Monterey Bay, Deep-Sea Res. Pt. II, 57, 1551-1556, 2010.

Schlining, B. and Jacobsen Stout, N.: MBARI's Video Annotation and Reference System. In: Proceedings of the Marine Technology Society/Institute of Electrical and Electronics Engineers Oceans Conference, Boston, Massachusetts, 1-5, 2006.

Schulz, J., Barz, K., Ayon, P., Lüdtke, A., Zielinski, O., Mengedoht, D., and Hirche, H. J.: Imaging of plankton 
specimens with the Lightframe On-sight Keyspecies Investigation (LOKI) system, J. Eur. Opt. Soc.-Rapid, 5S, 1-9, https://doi.org/10.2971/jeos.2010.10017s, 2010.

Stoner, A. W., Laurel, B. J., and Hurst, T. P.: Using a baited camera to assess relative abundance of juvenile Pacific cod: Field and laboratory trials, J. Exp. Mar. Biol. Ecol., 354, 202-211, 2008.

Stramma, L., Johnson, G. C., Sprintall, J., and Mohrholz, V.: Expanding Oxygen-Minimum Zones in the Tropical Oceans, Science, 320, 655-658, 2008.

Stramma, L., Prince, E. D., Schmidtko, S., Luo, J., Hoolihan, J. P., Visbeck, M., Wallace, D. W. R., Brandt, P., and Körtzinger, A.: Expansion of oxygen minimum zones may reduce available habitat for tropical pelagic fishes, Nat. Clim. Change, 2, 33-37, 2012.

Utne-Palm, A. C., Breen, M., Lokkeborg, S., and Humborstad, O. B.: Behavioural responses of krill and cod to artificial light in laboratory experiments, PloS One, 13, e0190918, 2018.

Webb, T. J., Vanden Berghe, E., and O'Dor, R.: Biodiversity's Big Wet Secret: The Global Distribution of Marine Biological Records Reveals Chronic Under-Exploration of the Deep Pelagic Ocean, PLoS ONE, 5, e10223, https://doi.org/10.1371/journal.pone.0010223, 2010.
Wiebe, P. H. and Benfield, M. C.: From the Hensen net toward fourdimensional biological oceanography, Prog. Oceanogr., 56, 7136, 2003.

Wishner, K. F., Outram, D. M., Seibel, B. A., Daly, K. L., and Williams, R. L.: Zooplankton in the eastern tropical north Pacific: Boundary effects of oxygen minimum zone expansion, Deep-Sea Res. Pt. I, 79, 122-140, 2013.

Youngbluth, M., Sørnes, T., Hosia, A., and Stemmann, L.: Vertical distribution and relative abundance of gelatinous zooplankton, in situ observations near the Mid-Atlantic Ridge, Deep-Sea Res. Pt. II, 55, 119-125, 2008. 